\title{
Effects of the EU Originated Debt Crisis on Turkey's Export
}

\author{
Serife Merve Kosaroglu \\ Cumhuriyet University \\ Haci Ahmet Karadas \\ Cumhuriyet University \\ Dr. Esengul Salihoglu \\ Cumhuriyet University
}

\begin{abstract}
The 2008 global financial crisis, which is originated from US, resumes its effects especially in members of EU. During global or domestic financial crisis waves, worsening on consumer and producer expectations, reduction in foreign capital inflows, and decrease in export are expected. Turkey makes a crucial part of its foreign trade with EU states. Therefore, developments on economies of EU states are reflected to Turkish economy directly or indirectly. This study examines the effects of the demand changes in $\mathrm{EU}$ on a global crisis wave to Turkey via Turkish export sector.
\end{abstract}

Keywords: Trade Balance, Export, Turkish Economy, Time Series, Trade Policy.

\section{INTRODUCTION}

Acceleration of the globalization trend in the 20th century, the rapid development of transportation and technology have led countries to international goods and capital flows. The liberalization trend started in foreign trade has increased the volume of international trade. The direct and indirect capital flows have accelerated depending on the increase of trade. Since the economic dependency of the countries increased, the power of the political, social and economic impacts occurred in a country to influence the other countries has increased. Especially the negative atmosphere due to the political and economic problems also shows negative effects on other countries. It is known that the economic crisis have contagion effects on other countries due to the contraction of the foreign trade volume, reduction of the direct and indirect capital flows.

The self-fulfilling structure and spreading to other countries have taken its place in the literature as second and third generation crisis models. After the 2008 crisis EU debt crisis first emerged seems to have a negative impact on developing countries later. The expectations for near future are the 2008 crises will cause economic crises in emerging countries. Since Turkey has extensive trade relations with EU, 
the contraction effects connected to debt crisis are seen in Turkish economy. Expansionist effects of the 2008 economic crisis has reveal a negative impact on Turkish economy. In addition to the contraction in the real sector, a time period was observed increased in macroeconomic problems such as contraction in foreign investment, rise in unemployment rate and increase in current account deficit.

In our study, we mainly investigate the negative impacts of the European debt crisis on Turkish economy. For this purpose, an econometric analyze is done in order to identify the effects of the relation between EU states' GDPs and public debts on Turkish export since the crisis spreads their negative effects by trade.

\section{ECONOMIC CRISIS AND FOREIGN TRADE}

The economic crisis are defined as severe fluctuations happens beyond an acceptable range in any one of commodity, service, production factor, and currency exchange market. Economic crises can be examined under two headings as real and financial crisis. The real sector crises emerge as a contraction of production and/or employment in commodity, service and labor markets. Financial crises are financial market collapses that can lead to devastating effects on real section of the economy and disrupts the efficient functioning of markets (Iş̧1 et. al., 2006:239).Financial and reel economic crises emerge for different reasons. Due to the international economic connections, crisis started in one country is reflected to other countries.

Economists examine the role of the financial crisis on foreign trade for two reasons. First, the trade deficit of the financial crisis have been shown to be one of the most important factors to mobilize. The current account deficit leads to the decrease of foreign sources. Krugman (1979) noted that foreign sources of money, such as the emergence of the crisis in the economy are more likely not enough. Second, the financial crisis can infect others from one country to trade links. The effects of economists to explain the impact of this type of contamination are trying to identify the channels through which it spread. Many studies due to the known economic ties between the countries foreign trade is done in this connection. The importance of foreign trade take action on the importance of open crisis is largely accepted in the foreign trade of the spread of the crisis is no consensus (Ma and Cheng, 2005:254). However, the contagion effects of the crisis between the countries is seen in various ways because of the influence of foreign trade.

The adverse impact of a financial crisis on capital accumulation is likely the combined outcome of several factors. Decreased demand for products and heightened uncertainty of potential return dampens the incentive to invest (Elwell, 2013:18). If a country 
enters the stage of recession, it also affects the countries that have trade relations with it. In the countries that experiences cyclical recession, demand decreases and imports fails. This situation results in reduction of exports and deficits on balance of payments of the countries have trade relations with it (Öztürk, 2012:159). Thus, developing countries with fragile economies becoming more vulnerable to external shocks, especially the rapid movements of the financial capital in and out of these economies cause the economic crisis (Değirmen et. al., 2006:466). The problems in trade financing potentials play part in the reduction of world trade as well as the lack of demand. There are important signals regarding the financial institutions have tightened the conditions of loans to finance the foreign trade. While this situation significantly increases the costs of foreign trade operations, it hinders the foreign trade in some cases. Another factor causing the costs to increase is the rise in insurance premiums originated from the crisis and in demand for insurance instruments due to the mutual mistrust (Acar, 2009: 2-4-9).

The current financial crisis started in developed countries, but reduced foreign investment and reduced demand for imports of commodities and labor-intensive products are having profound effects on developing countries. Continuing lack of demand in developed countries implies that developing countries need to enhance trade and finance linkages among themselves in order to foster economic growth. The inability of some companies to obtain insurance for orders they have placed with suppliers has caused them to curtail or shut down their production and sales activities. This problem has been aggravated by developments on the demand side, with households compelled to increase their savings to compensate for the fall in the value of their financial and real estate assets. Rising fears of unemployment have also led households to curtail consumption (Abreu, 2009:2-3).

\section{CRISIS OF 2008 AND THE EUROPEAN DEBT CRISIS}

Since the interest rates in the US stayed quite low from the beginning of 2000's, loans became attractive for the people in low level income groups. In particular, along with reelection of George W. Bush in 2004, there were some facilities such as tax benefits in order subprime groups to be able to buy house. The rate loan for subprime groups is mostly applied as the first two years are fixed and the rest is indexed in LIBOR. The movement of US interest rates from $1.5 \%$ to $5 \%$ in the period of 2004-2006 did not affect the subprime group who uses the loans. The raise of the interest rates by the US Central Bank (FED) from 2006 has put the housing sector into a major recession. After the house prices becomes cheaper than when they were bought, low level income group became unable to pay the loans regularly (Korkmaz and Tay, 2011:117). 
The global crisis that emerged in the USA started in the finance sector and then spread to overall economy. The outstanding loans led to bankruptcy of financial organizations and shook the confidence of consumers, and along with the decrease in the demand, implications of financial crisis occurred in the real sector as well. As a result of liquidity and confidence problem caused by the financial crisis, short term transactions such as foreign direct investment flow and portfolio investments also declined (Yavuzet. al., 2013:133).

When growth in the financial markets reached to significant levels, the crisis affected the all Europe since toxic papers, possessed by many European banks, are based on the US mortgage market. Many banks have shown weak balance against the risk due to the assets they posses and have suffered huge losses. Moreover, the uncertainty of the value of assets in their possession made it difficult to borrow money. With the global financial crisis, many European banks with balance sheets do not contain toxic papers has also come to the point of sinking as a result of excessive tightening of repayment of loans they provide to the housing sector (Eser and Ela, 2015: 211). Packages to rescue banks have activated so a crisis originating from banks have prevented. However, the negative impact of the rescue package and demand-side policies have led to public debt ratios above the rate set out in the Maastricht criteria. This situation has led to the debt crisis in the countries members of the European Union.

\section{EFFECTS ON THE TURKISH ECONOMY CRISIS}

The global financial crisis effects on developing and emerging countries in terms of several factors. The combination of declining commodity and manufactured export earnings, collapse of remittances, reversal of private capital flows, rising risk spreads, an extreme degree of credit squeeze affecting even trade finance and losses of asset values is giving rise to a sharp economic slowdown and even contraction in many parts of the developing world (Terzi, 2010:248,249; Shelburne, 2010:22). Although Turkey's strongest bond with Europe is the foreign trade, the share of EU in total exports of Turkey fell from 56\% to 39\% in the period of 2001-2012 (Aysan and Ermişoğlu, 2013: 20).

Turkey's economy is in a high degree of harmony with the world economy through trade and financial channels. Therefore, the crisis affected Turkey's economy is related to this harmony (Macovei, 2009: 1). The global crisis has affected the Turkish economy through three channels, namely expectation channel, trade channel and financial channel (Cömert and Çolak, 2014:7). The problems in global credit markets caused loss of consumer confidence, local uncertainty and deterioration in risk perception thus caused a decline in foreign 
trade (Macovei, 2009: 1). Turkey is affected by the large loss in export revenues due to the demand shock in EU as well as lack of money entry (Öniş, 2009: 57).

After the economic crisis experienced in the early 2000s in Turkish economy, the economic indicators have developed in a positive direction. In this context, there have been significant growth in Turkey's exports and imports after the crisis occurred in 2001 and this trend continued until the last quarter of 2008. Despite the unfavorable demand and supply conditions that emerged in the last quarter due to the global crisis, the ongoing increase in nine months of 2008 began to recession as the impact of the crisis became clear by the last quarter (TOBB, 2009: 90-91).

Due to the weight of the EU in Turkey's exports, Turkey's export performance depends on the demand conditions of the EU member states. Economic slowdown and recession in EU members affect the Turkish exporters and manufacturers as contraction (Yalçınkaya, 2012: 179, Born, 2013: 2). Trade relations between Turkey and Europe which is in crisis have decreased, current account deficit of Turkey has increased, macroeconomic data has deteriorated, and Turkey has taken its cue from global crisis with negative growth rate, increased unemployment and poverty. The current account deficit problem, which is the leading most important problem of Turkey, has increased with this crisis. Since the current account deficit and unemployment problems are connected to each other, an increase occurred in unemployment with current account deficit. Since unemployment comes with poverty, increase in social aid has been observed with state intervention as a part of the fight against poverty (http://sahipkiran.org /2015/01/12/kuresel-ekonomikkriz/, Date of Access: 23.03.2016).

In the long run, the euro crisis will continue to affect negatively the competitiveness of Turkish exports. But the decline in external demand and export bottlenecks can be financed with foreign currency arbitrage made by foreign direct investment (FDI). If the high rate of ROI offered by Turkey (investment transformation) is taken into account (6.5\%), there is more potential for attracting FDI from EU countries. Being outside the euro area and providing high ROI, can make Turkey the winner of the Euro crisis in the long term (Elitok and Straubhaar, 2010:8).

\section{LITERATURE}

There are several studies to investigate the effects of the economic crises on foreign trade and the national economy. Various methods and applications used for different countries. Some of these studies are:

- Lu Bai found out the financial crisis is the main factor that reduces the China's exports by using Gravity method for 2001-2010 period. 
- BalazsMuraközyanalyzed the decline in Hungary's export during 2008-2009 crisis. He found the decline in exports of foreign-funded companies is higher than the local firms.

- Görgand Spaliara investigated the response of UK's manufacturing companies to the recent financial crises in 2000-2009 period by using panel data set. According to the results of the study, the companies that started to export recently shows better performance in and out of the crisis than none-exporters.

- Neto and Romeu investigated the role of export diversification in determining the foreign trade output during the financial crisis. They tested Latin American countries with the data set that includes over 500 thousand observations by using Gravity model. Results of the study shows that industry and product density of Latin American countries effected the resistance of their foreign trade excessively during the financial crisis.

- Emirhan analyzed the effects of the global economic crisis of 2008-2009 on exports of Turkey and in particular on the different quality levels of exports. He used panel data of exports of Turkey to the EU countries at the industry level in the period of 2008q1 and 2009q4. He found that the medium quality industries have highest share in Turkey's exports to the EU countries on average. The findings of the study reveal that income elasticities vary across industries at different quality levels, and medium quality industries' exports are more sensitive to income changes than lower and higher quality industries.

- Tunçsiper and Bicen empirically investigated the export potential of Turkey to EU countries. Results of the study shows that in the long run economic growth or recession in the EU countries will affect Turkey's export in the same direction.

In our study, analysis is performed using annual data for the period of 1995-2012. In the analysis, the effects of external debt stock and GDP of EU on growth rate of Turkey's exports are investigated. The data set is taken from World Bank database.

There are several co-integration tests to estimate the relation between the series in econometric analysis. For I $(0)$ variables, conventional OLS is used. For I(1)variables Engle-Granger (1987) or Johansen (1991) methods are used. If the variables are integrated I(0) and I(1), ARDL: Autoregressive Distributed Lag (Pesaran and Shin, 1999 and Pesaran et. al., 2001) must be used to estimate the relation between the variables. 
While trying to estimate the relation between the variables, we firstly define an unrestricted error correction model:

$$
\begin{aligned}
\Delta Y_{t} & =\alpha_{0}+\beta_{1} Y_{t-1}+\sum_{i=1}^{n} \beta_{i+1} X_{i ;(t-1)}+\sum_{j=1}^{p} \theta_{j} \Delta Y_{(t-j)} \\
& +\sum_{k=1}^{q} \delta_{k} \Delta X_{1 ;(t-k)}+\cdots+\sum_{l=1}^{r} \gamma_{l} \Delta X_{n ;(t-l)}+u_{t}
\end{aligned}
$$

Where $Y$ is dependent variable, $X_{i}$ independent variables, $\beta_{i}$ $(i=1,2, \cdots, n), \theta_{\mathrm{j}}(j=1,2, \cdots, p), \delta_{\mathrm{k}} \quad(k=1,2, \cdots, q)$ and $\gamma_{1} \quad(l=1,2, \cdots, r)$ are coefficients, $\mathrm{u}_{\mathrm{t}}$ is error term.

An unrestricted error correction model (defined in (1)) is estimated and the significance of $\beta_{i}$ coefficients is evaluated by the help of Wald test and table values appeared in Pesaran et. al. (2001). The null hypothesis of this test is "there is no long run relation between the variables". That is,

$$
\text { for } \forall i, \quad H_{0}: \beta_{i}=0
$$

If the value of F-statistic calculated by Wald test is greater than the upper bound, then we can reject the null hypothesis. Therefore, it can be said that there is long run relation between the variables. However, if the value of F-statistic is less than the lower bound, the the null hypothesis cannot be rejected.

Graph: Data
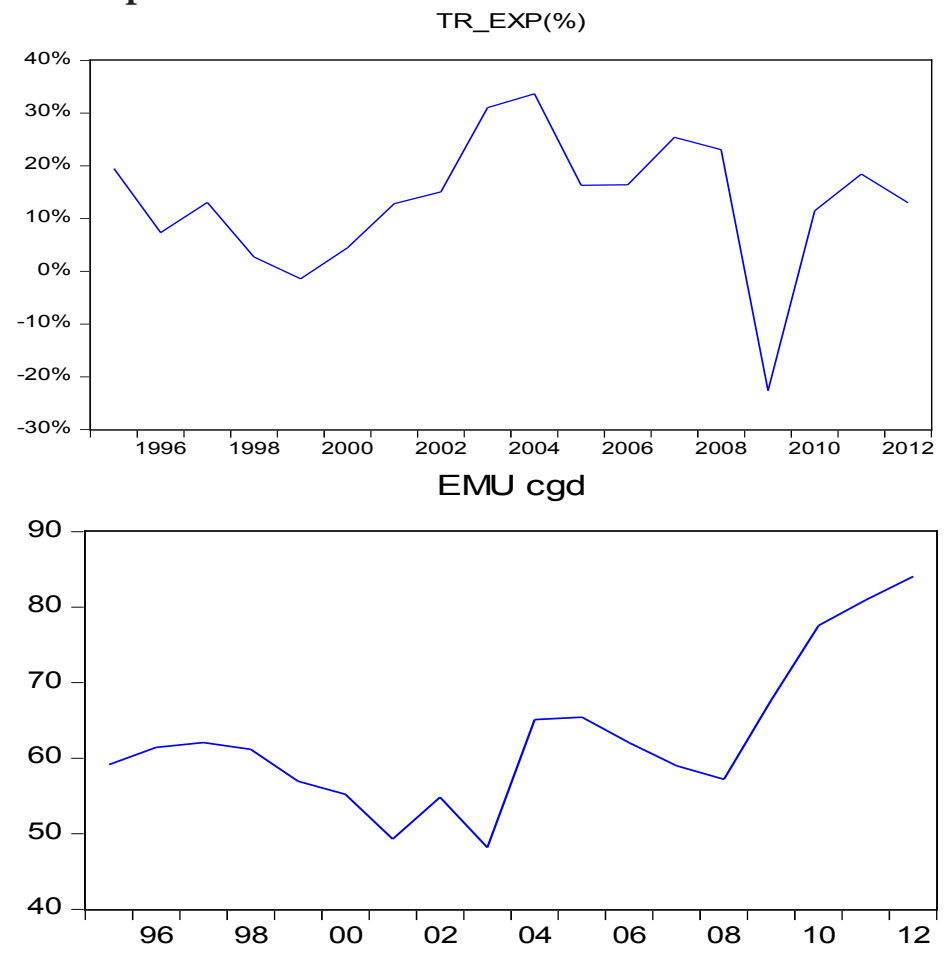


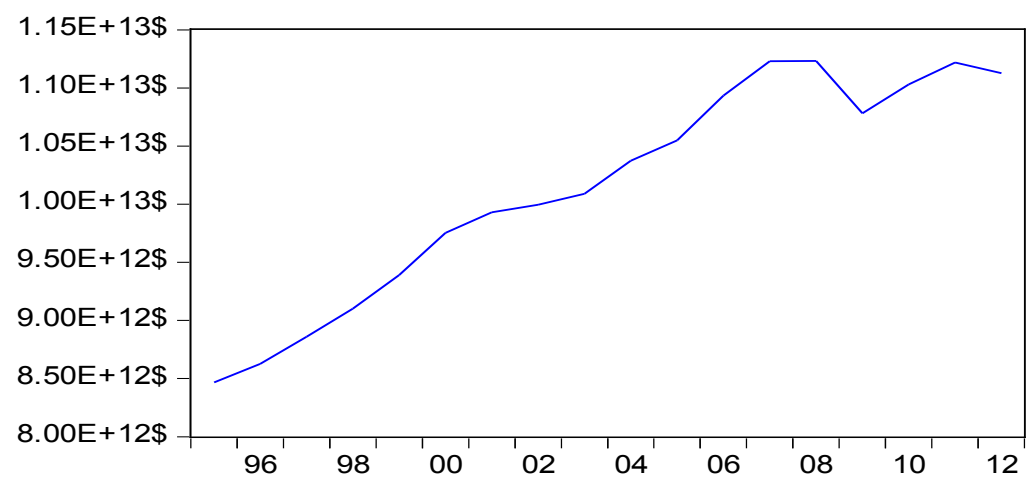

\subsection{Unit Root Tests}

In econometric analysis, regression models for non-stationary variables will give spurious results. There are several unit root tests to investigate stationary of the variables. Since the ADF (Augmented Dickey Fuller) test is the most common of all, ADF test is used in this study. The unit root test results are given in table 1.

Table 1: Unit Root Test Results

\begin{tabular}{|c|c|c|}
\hline \multirow{2}{*}{ Unit root Tests } & \multicolumn{2}{|c|}{ Augmented Dickey-Fuller test statistic } \\
\cline { 2 - 3 } & t-Statistic & Prob.* \\
\hline TR_EXP & $\mathbf{- 3 . 1 6 2 6 3 7}$ & 0.0407 \\
\hline EU_CGD & -0.374968 & 0.8931 \\
\hline DLNEUCGD & $\mathbf{- 4 . 4 7 5 4 9 2}$ & 0.0035 \\
\hline EU_GNI_C & -1.881576 & 0.3321 \\
\hline DLNEUGNI & $\mathbf{- 3 . 8 6 3 5 0 7}$ & 0.0422 \\
\hline
\end{tabular}

According to unit root test results, exports of Turkey (TR EXP) is stationary at level, external debt stock and GNI of EU are non-stationary at level (but stationary at first difference). The nonstationary variables are $\mathrm{LN}$-transformed into stationary.

\subsection{Bounds Test}

The equation of bound test for our model is like

$$
\begin{gathered}
T R_{-} E X P_{t}=\alpha_{0}+\beta_{1} L N E U C G D_{t-1}+\beta_{2} L N E U G N I_{t-1} \\
+\sum_{k=1}^{q} \delta_{j} \Delta(L N E U C G D)_{(t-j)}+\sum_{j=1}^{p} \theta_{j} \Delta(L N E U G N I)_{(t-j)}+u_{t}
\end{gathered}
$$

Where,

$T R \_E X P$ : Exports of Turkey

LNEUCGD: External debt stocks of EU

LNEUGNI: GNI of EU

The Wald test result of equation (2) is given in table 2. As seen in table, since the value of $\mathrm{F}$-statistic is greater than upper bound of $1 \%$ significance level, hypothesis can be rejected. Therefore, it can be said that there is a long run relation between the variables. 
Table 2: ARDL Bounds Test

\begin{tabular}{|c|c|}
\hline \multicolumn{2}{|c|}{ Null hypothesis : : No long-run relationships exist } \\
\hline \hline F-statistic & $\mathrm{k}$ \\
\hline $\mathbf{2 0 . 2 8 1 3 0}$ & $\mathbf{2}$ \\
\hline \multicolumn{3}{|c|}{ Critical Value Bounds (1\%) } \\
\hline $\mathbf{I}(\mathbf{0})$ & $\mathrm{I}(\mathbf{1})$ \\
6.34 & 7.52 \\
\hline
\end{tabular}

\subsection{ARDL}

Lag lengths for ARDL model is identified by Akaike information criterion in Eviews 9. In this study maximum lag length is set as 4 and $\operatorname{ARDL}(2,2,2)$ is identified by Akaike information criterion. The result of the model is given in Table 3 .

Table 3: ARDL $(2,2,2)$ Co-integrating and Long Run Form

\begin{tabular}{|c|c|c|c|c|}
\hline \multicolumn{5}{|c|}{ DependentVariable: TR_IHR } \\
\hline Variable & Coefficient & Std. Error & t-Statistic & Prob. \\
\hline D(TR_IHR(-1)) & 1.135998 & 0.225193 & 5.044560 & 0.0040 \\
\hline D(DLNEUGNI) & 1201.513585 & 134.812697 & 8.912466 & 0.0003 \\
\hline D(DLNEUGNI(-1)) & -573.516587 & 199.132463 & -2.880076 & 0.0346 \\
\hline D(DLNEUCGD) & -63.528991 & 21.880750 & -2.903419 & 0.0337 \\
\hline D(DLNEUCGD(-1)) & 59.993097 & 16.117745 & 3.722177 & 0.0137 \\
\hline D(@TREND()) & 3.090586 & 0.544463 & 5.676398 & 0.0024 \\
\hline CointEq(-1) & -0.530359 & 0.186117 & -2.849599 & 0.0358 \\
\hline \multicolumn{5}{|c|}{$\begin{array}{c}\text { Cointeq }=\text { TR_IHR }-((1400.6126) D L N E U G N I-(265.7858) D L N E U C G D \\
-60.8505+(5.8273) @ T R E N D)\end{array}$} \\
\hline \multicolumn{5}{|c|}{ Long Run Coefficients } \\
\hline Variable & Coefficient & Std. Error & t-Statistic & Prob. \\
\hline DLNEUGNI & 1400.612571 & 463.085970 & 3.024520 & 0.0293 \\
\hline DLNEUCGD & -265.785779 & 167.560316 & -1.586210 & 0.1736 \\
\hline $\mathrm{C}$ & -60.850508 & 23.303497 & -2.611218 & 0.0476 \\
\hline @TREND & 5.827346 & 2.095282 & 2.781175 & 0.0388 \\
\hline \multicolumn{5}{|c|}{$\mathrm{R}^{2}=0.748010 \overline{\mathrm{R}}^{2}=0.294429 \mathrm{~F}=1.649120$} \\
\hline
\end{tabular}

According to ARDL co-integration and long run form results, the coefficient of error correction term (cointreg) is found negative and statistically significant. Since the coefficient is (-0.530359), it means that adeviation from equilibrium in the short run will return to lung run equilibrium in about 2 sessions.

\section{EVALUATION AND CONCLUSION}

International trade has increased the economic interdependence between countries. Positive developments such as the economic growth increases the foreign trade of the country and also contribute to the economies of other countries. However, 
the economic reasons such as demand reduction, current account deficits, and shortness of foreign currency reduce the foreign exchange and cause negative effects on other countries. Especially, the progress of these negative economic developments results in economic crisis and causes different long-termed and wide-scaled economic crisis.

The contractionary effect on demand and increasing effect on public debt and economic recession of 2008 crisis has led to the European debt crisis. Turkish economy is affected from 2008 crisis at most in 2009. However, in the recent period it is subject to the effects of the debt crisis. The lack of demand occurred in Europe has reduced Turkey's most important export potential. According to our ARDL approach, a decrease in GNI of EU effects the growth of Turkish exports negatively.

In order to minimize the negative effects of the 2008 and the debt crises, Turkey should take measures to support export sector. In addition to this, new markets must be found. Thus, the national economy will be affected from the effects of global crises at minimum.

\section{REFERENCES}

Abreu Marcelo de Paiva, Manmohan Agarwal, Sergey Kadochnikov, Mia Mikic, John Whalley and Yu Yongding, The Effect of the World Financial Crisis on Developing Countries: An Initial Assessment, The Centre for International Governance Innovation, 2009.

Acar Ozan, Türkiye'de Dış Ticaret ve Dış Ticaretin Finansmanı Durum Değerlendirmesi, 2009.

Aysan Ahmet Faruk and Ergun Ermişoğlu, Eurozone Debt Crisis and its Effects on Turkish Economy, MPRA Paper, No.50501, 2013.

Bai Lu, Effects of Global Financial Crisis on Chinese Export: A Gravity Model Study, Jönköping International Business Scholl, Master Thesis, 2012.

Born Chad P., Trade Policy Flexibilities and Turkey Tariffs, Antidumping, Safeguards, and WTO Dispute Settlement, Policy Research Working Paper 6322, 2013.

Cömert Hasan ve Selman Çolak, The Impacts of the Global Crisis on the Turkish Economy and Policy Responses, ERC Working Papers in Economics, 2014.

Değirmen Süleyman, Ahmet Şengönül ve İsmail Tuncer, Kriz Erken Uyarı Sinyalleri Olarak Reel Ekonomi Göstergeleri, Ekonomik Kriz Öncesi Erken Uyarı Sistemleri, ArıkanYayınevi, İstanbul, 2006.

Elitok Seçil Paçacı and Thomas Straubhaar, The Turkish Economy: A Winner of the Euro Crisis?, HWWI Policy Paper, 2010.

Elwell Craing K., Economic Recovery: Sustaining U.S. Economic Growth in a Post-Crisis Economy, Congressional Research Service, 2013.

Emirhan Pinar Narin, The Effects of the 2008-2009 Crisis on Turkish Exports: Does Quality Matter?, Izmir Review of Social Sciences Vol:2, No:2, 2015.

Eser Levent Yahya ve Mehmet Ela, Avrupa Borç Krizi: Nasıl, Neden ve Nereye?, Eskişehir Osmangazi Üniversitesi İİBF Dergisi, 2015.

Görg Holger and Marina-Eliza Spaliara, Exporters in the Financial Crisis, Kiel Working Paper, No.1919, 2014. 
Korkmaz Esfender ve Arzu Tay, Küresel Kriz, Türkiye Etkileri ve Çözüm

Önerileri, Kafkas Üniversitesi İIBF Dergisi, C:1, S:2, 2011.

Işık Nihat, Mehmet Alagöz ve Metin Yıldırım, 1990 Sonrası Türkiye’de Yaşanan

Krizler:1994, 2000 ve 2001 Krizleri, Ekonomik Kriz Öncesi

Erken Uyarı Sistemleri, Arıkan Yayınevi, İstanbul, 2006.

Ma Zihui and Leonard Cheng, The Effects of Financial Crises on International

Trade, NBER-East Asia Seminar on Economics, Volume 14, 2005.

Macovei Mihai, Growth and Economic Crises in Turkey: Leaving Behind a

Turbulent Past?, European Economy Economic Papers 386, 2009.

Muraközy Balazs, Margins of Hungarian Exports During Crisis, EFIGE Working Paper, No:53, 2012.

Neto Nelson Camanho da Costa, Rafael Romeu, Did Export Diversification Soften the Global Financial Crisis?, IMF Working Paper, 2011.

Öniş Ziya, Crises and Transformations in Turkish Political Economy, Turkish Policy, V:9, N:3, 2009.

Öztürk Nazım, Dış Ticaret Kuram, Politika, Uygulama, Ekin Basım Yayın Dağıtım, Bursa, 2012.

Pesaran M. Hashem, Richard J. Smith and Yongcheol Shin, Bounds Testing Approaches to the Analysis of Long Run Relationships, Journal of Applied Econometrics, 16/3, 2001.

Pesaran M. Hashem and Yongcheol Shin, An Autoregressive Distributed Lag Modelling Approach to Cointegration Analysis, 1999.

Shelburne Robert C., The Global Financial Crisis and Impact on Trade: The World and The European Emerging Economies, Discussion Paper Series, No:2010.2, 2010.

Terzi Nuray, Global Financial Crisis And The Effects Of Its On Turkish Economy, 6th International Scientific Conference, 2010.

TOBB 2009 Ekonomik Rapor, 2009.

Tunçsiper Bedriye ve Ömer Faruk Biçen, Avrupa Borç Krizinin Türkiye’nin İhracatı Üzerindeki Etkileri, International Conference On Eurasian Economies, 2013.

Türkay Hakan ve Muzaffer Demirbaş, Türkiye Ekonomisinde Yatırımların Faiz ve Gelir İlişkisinin ARDL Yaklaşımı İle Analizi, Akademik Yaklaşımlar Dergisi, V:3, I:2, 2012.

Yalçınkaya Onur, Analysis of Turkish Financial Market With Focus on EU Membership, Master Thesis, 2012.

Yavuz Ali, Ceyda Şataf ve Serap Gül Kır, Avrupa'da Borç Krizi ve Çözüm Arayışları, Afyon Kocatepe Üniversitesi İİBF Degisi, 2013.

http://sahipkiran.org/2015/01/12/kuresel-ekonomik-kriz/, Date of Access: 23.03.2016 